\title{
ACUTE TOXICITY STUDIES AND EVALUATION OF ANALGESIC PROPERTY OF TECTONA GRANDIS METHANOLIC SEED EXTRACT IN SWISS ALBINO MICE
}

\author{
JHANSI RANI G, LAKSHMI BHAVANI N* \\ Department of Botany, University College of Science, Saifabad, Osmania University, Hyderabad, Telangana, India. \\ Email: jhansirani2431@gmail.com
}

Received: 18 June 2019, Revised and Accepted: 20 September 2019

\section{ABSTRACT}

Objective: Tectona grandis which is well known as teak possesses a wide range of applications in Indian and African folklore medicine. All the plant parts are having diverse bioactivities, especially the seeds, having hair growth-promoting activity, anti-inflammatory, and antimicrobial activity. Xanthones, proteins, amino acids, and fatty acids have been isolated from the oil and seeds of $T$. grandis.

Methods: The present study was to explore the antinociceptive properties of methanolic seed extract of T. grandis. Dried seeds of the plant were defatted with non-polar solvents such as petroleum ether and extracted with methanol. Acetic acid-induced writhing test, tail flick test, and tail immersion test were employed for the extract using Swiss albino mice.

Results: From the results, it is clear that the methanolic teak seed extract is safe at $1000 \mathrm{mg} / \mathrm{kg}$ and having a potent analgesic property (at a dose of $200-250 \mathrm{mg} / \mathrm{kg}$ body weight) by inhibiting pain response time.

Conclusion: It can be concluded that the methanolic seed extract of $T$. grandis is analgesic in nature. It is considered as safe and the activity may be due to the presence of various bioactive chemicals such as flavonoids, xanthones, and glycosides.

Keywords: Tectona grandis, Acute toxicity, Analgesic, Acetic acid-induced writhing, Tail flick, Tail immersion.

(c) 2019 The Authors. Published by Innovare Academic Sciences Pvt Ltd. This is an open access article under the CC BY license (http://creativecommons. org/licenses/by/4. 0/) DOI: http://dx.doi.org/10.22159/ajpcr.2019.v12i11.34605

\section{INTRODUCTION}

Tectona grandis Linn. is a large deciduous tree $30-35 \mathrm{~m}$ tall. It is a well-known tree for its typical strong trunk, having good commercial value in timber industry [1]. The whole plant is having medicinal importance reported to cure several ailments according to Indian traditional system of medicines. The ample literature reveals that the plant is used in the treatment of diabetes, pains, skin allergies such as scabies, respiratory tract infections, and urinary tract infections, as diuretic, sedative, and laxative [2-5]. Various plant parts of T. grandis are having ethnopharmacological importance. Diversified phytoconstituents such as tannins, glycosides, sterols, and terpenoids were reported for T. grandis [6], which may be culpable for its wide range of pharmacological activities including antibacterial [7], antifungal [8], antioxidant [9], analgesic, antiinflammatory [10], antidiabetic, diuretic [11,12], antipyretic [13], wound healing [14], antiulcer [15], anticancer [16], and hair growth-promoting activities [17]. The seeds are reported to show antimicrobial [18], antioxidant, and anti-alopecic activity. However, there is no evidence of the analgesic properties of $T$. grandis.

Pain and inflammation are the incessant problems over the sphere. Nonsteroidal anti-inflammatory drugs (NSAIDs) are the primary choice for pain and inflammation. Due to the ulcers, hemorrhage, liver damage, and renal damage constraints of NSAIDs, there is always a need to develop safer analgesics [19]. In our current study, we are evaluating the analgesic activity of methanolic seed extract of $T$. grandis.

\section{METHODS}

\section{Plant material}

T. grandis fruits were collected in the month of February 2017 in Hyderabad and were identified by Dr. N. Sivaraj, Senior Scientist (Eco Botany), National Bureau of Plant Genetic Resources, Rajendranagar,
Hyderabad, seed specimens have been deposited. Extraction of T. grandis seeds: $5 \mathrm{~kg}$ of the fresh seeds were shade dried at temperature $25-30^{\circ} \mathrm{C}$ for 7 days. The dried seeds were powdered in a grinder. The alcoholic extract of the seeds was prepared by subjecting to repetitive maceration for 2 weeks with methanol after defatting with n-hexane. The extract was evaporated to dryness with rotary evaporator and lyophilized to get powder. The percentage of yield was calculated as $6 \%$ and the final methanolic extract was used for the studies.

\section{Phytochemical screening}

Various qualitative phytochemical tests were performed to confirm the presence of various secondary metabolites using standard protocols.

\section{Experimental animals}

Swiss albino mice (25-35 g) were used for the pharmacological screening from Sainath Agencies, Musheerabad, Hyderabad. Animals were randomly divided into groups before the commencement of the experiment; the mice were acclimatized in polypropylene cages for a period of 10 days under temperature $\left(26 \pm 2^{\circ} \mathrm{C}\right)$, relative humidity (45-55\%), and dark/light cycle for a period of $12 \mathrm{~h}$. Rodent pellet diet was supplied and water ad libitum. The Institutional Animal Ethics Committee has approved (CPCSEA/IAES/JLS/006/01/17/005) the study protocol before the commencement of the experiment.

\section{Acute toxicity studies}

Acute toxicity studies have been performed according to the Organisation for Economic Co-operation and Development guidelines 423 in two phases. After grouping animals into six, a single dose of 10, 50, 100, 500, and $1000 \mathrm{mg} / \mathrm{kg}$ (dissolved in water) followed by normal saline to the control was given. The mice were observed for mortality and considerable bodily changes for a period of 14 days. In the second phase, a group of six having a single dose of 1000, 1250, 1500, and $2000 \mathrm{mg} / \mathrm{kg}$ was administered and observed for behavioral and physiological variations such as body weight, food-water intake, excretion, and recorded [20]. 
Analgesic activity of methanolic seed extract in albino mice Acetic acid induced-writhing test

The experiment was performed by the procedure described by Koster and Anderson [21,22]. Swiss albino mice of both sexes were used for this experiment and divided into three groups of six animals each. The control group was administered with normal saline solution, the test groups were administered with $200 \mathrm{mg} / \mathrm{kg}$ of methanolic seed extract dissolved in water. The standard group was administered with a dose of $25 \mathrm{mg} / \mathrm{kg}$ standard diclofenac sodium prepared in water. Food was restricted during experiments. Writhing's was induced $30 \mathrm{~min}$ after the last dose by intraperitoneal injection of $10 \mathrm{ml} / \mathrm{kg}$ of $0.6 \%$ acetic acid in distilled water. The number of writhing that is a number of abdominal contractions, trunk twist responses, and extension of hind limbs was recorded immediately for a period of $10 \mathrm{~min}$. The percentage inhibition of writhing's for all the groups was calculated using the formula:

\section{Average of control group - Average of test Average of standard}

\section{Tail flick test}

This experiment was done by measuring the reaction latencies of mice [23]. The basal reaction time of mice to the heat was recorded by locating the tip of the tail on a radiant analgesiometer. The tail flick response was taken as the endpoint. The animals were divided into three groups (control, standard, and test) each containing six animals. The control group received the normal saline solution, the standard group received a dose of $2 \mathrm{mg} / \mathrm{kg}$ morphine sulfate subcutaneously, and the test group received a dose of $250 \mathrm{mg} / \mathrm{kg} \mathrm{T}$. grandis methanolic seed extract. The latent period of the tail flick response was determined at 30,60 , and $90 \mathrm{~min}$ after the administration of the samples. The cutoff period time was set as $15 \mathrm{~s}$ to avoid the skin damage. The percentage elongation of the time was calculated for the analgesic activity

\section{Tail immersion method}

The tail immersion method is also similar to the tail flick method [24]. The animals were divided into three groups (control, standard, and test) each containing six animals. The control group received the normal saline solution, the standard group received a dose of $2 \mathrm{mg} / \mathrm{kg}$ morphine sulfate subcutaneously, and the test group received a dose of

Table 1: Preliminary phytochemical screening of methanolic seed extract of Tectona grandis

\begin{tabular}{ll}
\hline Phytochemicals & Present or Absent \\
\hline Alkaloids & - \\
Glycosides & + \\
Flavonoids & + \\
Terpenoids & + \\
Steroids & + \\
Tannins & + \\
Proteins & + \\
Carbohydrates & + \\
Amino acids & + \\
\hline
\end{tabular}

+ : Indicates the presence and, -: Indicates the absence of phytochemicals
$250 \mathrm{mg} / \mathrm{kg} \mathrm{T.} \mathrm{grandis} \mathrm{methanolic} \mathrm{seed} \mathrm{extract.} \mathrm{The} \mathrm{basal} \mathrm{reaction} \mathrm{time}$ of mice to the heat was recorded by locating the tip (around 4-5 cm) of the tail in hot water $\left(55^{\circ} \mathrm{C} \pm 2\right)$. The time taken to withdraw its tail from the hot water was taken as the endpoint. The latent period of the tail removal response was determined at 30,60, and $90 \mathrm{~min}$ after the administration of the samples. The cut-off period time was set as $15 \mathrm{~s}$ to avoid the skin damage. The percentage elongation of the time was calculated for the analgesic activity.

\section{RESULTS AND DISCUSSION}

\section{Preliminary phytochemical analysis}

Preliminary phytochemical analysis of methanolic seed extract was done using standard reagents and protocols. The results (Table 1) revealed the presence of various phytochemicals such as glycosides, flavonoids, terpenoids, tannins, proteins, amino acids, carbohydrates, and steroids.

\section{Acetic acid-induced writhing test}

The acetic acid-induced writhing test can be used for screening peripheral and central analgesic properties of the drugs. The pain induced by the noxious substances like intraperitoneally administered acetic acid may be due to the release of some endogenous pain nerve stimulants [25] or pain mediators or by the release of prostaglandins which will sensitize the nociceptors [26]. The peripheral analgesic property can be examined by the writhing responses such as abdominal constrictions, trunk twisting, and extension of hind limbs induced by acetic acid. NSAIDs interfere in the transduction mechanism of primary afferent nociceptors by inhibiting cyclooxygenase in peripheral tissues [27]. Our results (Table 2) showed that T. grandis methanolic seed extract significantly $(\mathrm{p}<0.001)$ reduced the number of writhing responses in acetic acid-induced mice when compared with the control and standard diclofenac sodium. Interestingly, the extract at a dose of $200 \mathrm{mg} / \mathrm{kg}$ had considerable percentage inhibition than the standard that is diclofenac sodium.

\section{Tail flick method}

Tail flick method was carried in the mice and the results are depicted in Table 3. The control group showed no difference in the responses before and after the treatment with normal saline solution. Animals that received the test sample $(250 \mathrm{mg} / \mathrm{kg})$ showed statistically significant latency time $(7.4 \pm 0.4)$ compared to the standard drug $(7.7 \pm 0.3)$.

\section{Tail immersion method}

Tail immersion method was also carried and the results are illustrated in Table 4. The control group that received normal saline solution did not show any difference in the tail withdrawal time before and after the treatment. The test group $(250 \mathrm{mg} / \mathrm{kg})$ showed statistically significant latency time $(7.3 \pm 0.2)$ compared to the standard drug $(7.8 \pm 0.3)$

The analgesic activity of the extract may be by inhibiting prostaglandin synthesis and/or by involving in the peripheral pain mechanism. Primary qualitative analysis by different chemical tests for the methanolic seed extract of $T$. grandis showed the presence of various phytochemicals including tannins, flavonoids, glycosides, and saponins which may be responsible for the activity. However, further investigation on its phytochemistry is needed to identify the specific phytochemical components which are responsible for the activity.

Table 2: Effect of methanolic seed extract of Tectona grandis on acetic acid-induced writhing behavior in mice

\begin{tabular}{lllll}
\hline S. No. & Group & \multicolumn{2}{l}{ Total writhing responses } & Total \\
\cline { 3 - 4 } & & EHL & ABC & TT \\
\hline 1. & Control & $45 \pm 0.15$ & $28 \pm 0.11$ & $31 \pm 0.12$ \\
2. & Test & $42 \pm 1.23$ & $09 \pm 1.3^{* * *}$ & $104 \pm 0.76$ \\
3. & Standard & $22 \pm 0.12^{* *}$ & $11 \pm 0.65^{* *}$ & $61 \pm 0.18^{* *}$ \\
\hline
\end{tabular}

EHL: Extension of hind limbs, ABC: Abdominal constrictions, TT: Trunk twisting. Values are expressed in mean \pm standard error of the mean. Data compared against positive control group. One-way ANOVA, ${ }^{* *} \mathrm{p}<0.01$ and ${ }^{* * *} \mathrm{p}<0.001$ were considered statistically significant when compared to control using Tukey-Kramer multiple comparison test 
Table 3: Protective effect of methanolic seed extract of Tectona grandis on tail withdrawal reflexes induced by tail flick method in mice

\begin{tabular}{llll}
\hline Drugs & $\begin{array}{l}\text { Before } \\
\text { treatment }\end{array}$ & $\begin{array}{l}\text { After } \\
\text { treatment }\end{array}$ & \% Inhibition \\
\hline Control & $5.73 \pm 0.2$ & $5.7 \pm 0.3$ & 0 \\
Test & $5.7 \pm 0.1$ & $7.4 \pm 0.4^{*}$ & 74.02 \\
Standard & $5.6 \pm 0.3$ & $7.7 \pm 0.3^{*}$ & 75.67 \\
\hline
\end{tabular}

Values are expressed in mean \pm standard error of the mean. Data compared against positive control group. One-way ANOVA, ${ }^{*} \mathrm{p}<0.05$ was considered statistically significant when compared to control using Tukey-Kramer multiple comparison test

Table 4: Protective effect of methanolic seed extract of Tectona grandis on tail withdrawal reflexes induced by tail immersion method in mice

\begin{tabular}{llll}
\hline Drugs & $\begin{array}{l}\text { Before } \\
\text { treatment }\end{array}$ & $\begin{array}{l}\text { After } \\
\text { treatment }\end{array}$ & $\begin{array}{l}\text { \% } \\
\text { Inhibition }\end{array}$ \\
\hline Control & $5.4 \pm 0.2$ & $5.4 \pm 0.2$ & 0 \\
Test & $5.5 \pm 0.3$ & $7.3 \pm 0.2^{*}$ & $70.51^{*}$ \\
Standard & $5.5 \pm 0.2$ & $7.8 \pm 0.3$ & 75.34 \\
\hline
\end{tabular}

Values are expressed in mean \pm standard error of the mean. Data compared against positive control group. One-way ANOVA, ${ }^{*} \mathrm{p}<0.05$ was considered statistically significant when compared to control using Tukey-Kramer multiple comparison test

\section{CONCLUSION}

To curb the results, the current investigation affirms the analgesic potency of methanolic seed extract of T. grandis in Swiss albino mice. The activity may be by peripheral and/or by a central mechanism. Further investigation is indispensable to understand and validate the results and to isolate bioactive components from the seeds. It is also essential to develop an advanced model for a better understanding of the literal mechanism involved in the analgesic activity.

\section{ACKNOWLEDGMENT}

The authors are thankful to the Department of Botany, Osmania University, for providing necessary facilities.

\section{AUTHORS' CONTRIBUTIONS}

All the authors contributed equally.

\section{CONFLICTS OF INTEREST}

The authors declared that they have no conflicts of interest.

\section{REFERENCES}

1. Tewari DN. A monograph on Teak (Tectona grandis Linn.). Dehra Dun, India: International Book Distributors; 1992.

2. US National Plant Germplasm System. GRIN Taxonomy for PlantsTectona. United States Department of Agriculture. United States: US National Plant Germplasm System; 2013. p. 22.

3. Kaosa-ard A. Teak its natural distribution and related factors. Nat Hist Bull Siam Soc 1981;29:55-74.

4. Nayeem N, Karvekar MD. Analgesic and anti inflammatory activity of the methanolic extract of the frontal leaves of Tectona grandis. Int $\mathrm{J}$
Pharmacol 2010;8:1531-76.

5. Ghaisas M, Navghare V, Takawale A, Zope V, Tanwar M, Deshpande A, et al. Effect of Tectona grandis Linn. On dexamethasone-induced insulin resistance in mice. J Ethnopharmacol 2009;122:304-7.

6. Gupta PK, Singh P. A naphthoquinone derivative from Tectona grandis (Linn.). J Asian Nat Prod Res 2004;6:237-40.

7. Astiti NP, Suprapta DN. Antifungal activity of Teak (Tectona grandis L.F) against Arthrinium Phaeospermum (Corda), the cause of wood decay on Albizia falcataria (L.) Fosberg. J Int Soc Southeast Asian Agric Sci 2009; 18:62-9.

8. Goswami DV, Sonawane LL, Nirmal SA, Patil MJ. Evaluation of antiasthmatic activity of Tectona grandis Linn. Bark. Int J Pharm Sci Res 2009;1:10-6.

9. Shruthi DP, Sunith KE, Kumari EH, Govindappa M, Siddalingeshwera KG. Phytochemical screening, antioxidant and antiinflammatory activity of different extract from leaf, bark and stem of Tectona grandis. Int J Res Pharmacol Pharmacother 2009;1:140-6.

10. Ramachandran S, Kanth BR, Rajasekaran A, Kumar KT. Evaluation of anti-inflammatory and analgesic potential of methanolic extract of Tectona grandis flowers. Asian Pac J Trop Biomed 2009;1:155-8.

11. Vipin PS, Samanta KC. Hypoglycemic activity of methanolic extract of Tectona grandis Linn. Root in alloxan induced diabetic rat. J Appl Pharm Sci 2009; 1:106-9.

12. Ramachandran S, Rajasekaran A, Kumar KT. Antidiabetic, antihyperlipidemic and antioxidant potential of methanol extract of Tectona grandis flowers in streptozotocin induced diabetic rats. Asian Pac J Trop Med 2011;4:624-31

13. Priyanka S, Pooja VS, Samanta KC, Rathore KS. Antipyretic activity of methanolic extract of root of Tectona grandis on albino rats. J Pharmacol Toxicol 2009;1:28-33.

14. Majumdar M, Nayeem N, Kamath JV, Asad M. Evaluation of Tectona grandis leaves for wound healing activity. Pak J Pharm Sci 2007;20:120-4.

15. Goel RK, Pathak NK, Biswas M, Pandey VB, Sanyal AK. Effect of lapachol, a naphthaquinone isolated from Tectona grandis, on experimental peptic ulcer and gastric secretion. J Pharm Pharmacol 1987;39:138-40.

16. Balassiano IT, De Paulo SA, Henriques Silva N, Cabral MC, da Gloria da Costa Carvalho M. Demonstration of the lapachol as a potential drug for reducing cancer metastasis. Oncol Rep 2005;13:329-33.

17. Hidayat H, Karsten K, Ahmed VU, Miana GA, Green IR. Lapachol an overview. ARKIVOC 2007;2:145-71.

18. Bitchagno GT, Sama Fonkeng L, Kopa TK, Tala MF, Kamdem Wabo H, Tume CB, et al. Antibacterial activity of ethanolic extract and compounds from fruits of Tectona grandis (Verbenaceae). BMC Complement Altern Med 2015;15:265.

19. Smolinske SC, Hall AH, Vandenberg SA. Toxic effects of nonsteroidal anti-inflammatory drugs in overdose. Drug Saf 1990;5:252-74.

20. Dokuparthi SK, Khan A, Anusha A, Bee M, Shaibaz MD, Shahajeb S, et al. Acute oral toxicity study of Tectona grandis Linn. methanolic seed extract in albino mice. J Phytopharmacol 2017;6:183-5.

21. Koster R, Anderson M, De Beer EJ. Acetic acid-induced analgesic screening. Fed Proc 1959;18:412-7.

22. Iyabo M, Abubakar A, Abubakar K, Tijjani R, Giaze. Analgesic effect and anti-inflammatory activity of aqueous extract of Boswellia dalzielii (Burseraceae) stem bark. Int J Pharm Pharm Sci 2018;10:139-42.

23. Fred E, D'Amour, Smoth DL. A method for determining the loss of pain sensation. J Pharmacol Exp Ther 1941;72:74-9.

24. Zahid H, Rizwani GH, Shareef H, Ahmed M, Hina B. Analgesic and antipyretic activities of Hibiscus schizopetalus (Mast.) hook. Int J Pharm Pharm Sci 2012;4:21821

25. Raj PP. Pain mechanisms. In: Pain Medicine: A Comprehensive Review. $1^{\text {st }}$ ed. Saint Louis, MO, USA: Mosby-Year Book; 1996. p. 12-23.

26. Vasudevan M, Gunnam KK, Parle M. Antinociceptive and antiinflammatory properties of Daucus carota seeds extract. J Health Sci 2006;52:598-606.

27. Fields HL. In: Day PW, editor. Analgesic Drugs. $1^{\text {st }}$ ed. New York, USA: McGraw-Hill; 1987. p. 272 